\title{
CONTENTS
}

The Recarving and Alteration of Maya Monuments.

R. G. BAKER

Cerrillos, an Early Paracas Site in Ica, Peru

D. T. WALLACE

The Microlithic Character of Neolithic Cultures in Central

Asia, Trans-Baikal, and Manchuria.............................. LARICHEV

Glyphic Evidence for a Dynastic Sequence at Quiriguá, Guatemala ..........D. H. KeLLEY

The Mandeville Site in Southwest Georgia...J. H. Kellar, A. R. Kelly, and E. V. McMichael

Plant Material from a Cave on the Río Zape, Durango,

Mexico ..........R. H. Brooks, Lawrence Kaplan, H. C. Cutler, and T. W. Whitaker

Metal Artifacts from Amapa, Nayarit, Mexico.................... D. M. Pendergast

A Ceremonial Cave on Bonita Creek, Arizona .....................W. W. WASLEY

ALFred LouIs KROEBER -1876-1960

\section{FACTS AND COMMENTS}

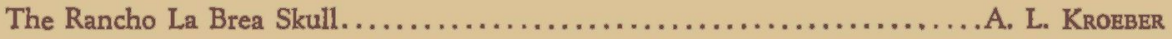

The Arlington Spring Site, Santa Rosa Island, California ................... C. ORR

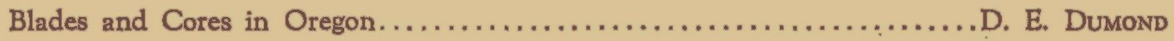

Correlations between Archaic Cultures of Southern California

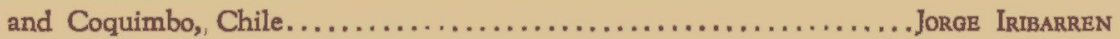

A Distinction between Blades and Microblades in the American Arctic....W. E. TAYLOR, JR.

\section{REVIEWS}

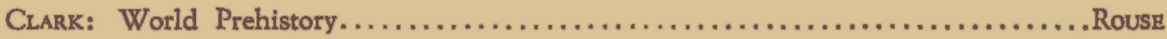

WOODBURY (EDTTOR): Abstracts of New World Archaeology....................BYER

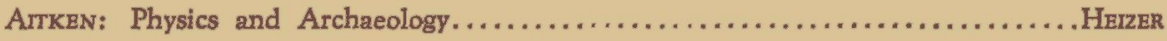

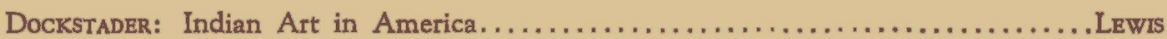

Mrad and Bunzer, (edrtors): The Golden Age of American Anthropology..........Strong 430

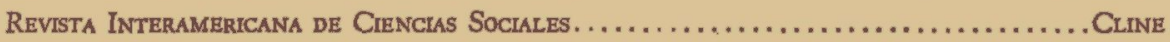

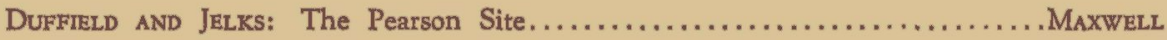

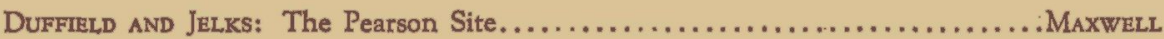

WENDORF (ASSEMBLER): Paleoecology of the Llano Estacado................... JeLINEK

Woodsury: Prehistoric Agriculture at Point of Pines..................... DaffukU

Grosscur: The Culture History of Lovelock Cave..........................

MAssey ANd OsBorne: A Burial Cave in Baja California $\ldots \ldots \ldots \ldots \ldots \ldots \ldots \ldots$ Ascher

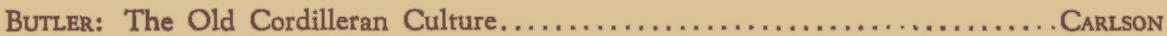

CRESSMAn AND orhers: Cultural Sequences at The Dalles $\ldots \ldots \ldots \ldots \ldots \ldots \ldots$ Borden

WaUCHoPE: Ten Years of Middle American Archaeology..................THOMPSON 432 431 432 433 434 435 435

Spratuing: More Human than Divine.........................ProskouriakofF 438

ANDREws: Preliminary Report of the 1959-60 . . Dzibilchaltun Program............. CoE 439

Mintz (CompILER): Papers in Caribbean Anthropology Howard 440

Announcement of the Annual Meeting. $\ldots \ldots \ldots \ldots \ldots \ldots \ldots \ldots \ldots \ldots \ldots \ldots \ldots \ldots \ldots \ldots, 426$

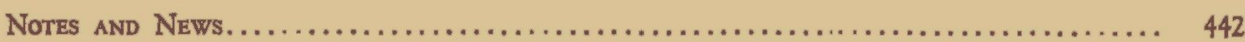




\section{PUBLICATIONS OF THE SOCIETY FOR AMERICAN ARCHAEOLOGY}

Send orders for all publications (except Memoir 14 and Archives of Archaeology) to Society for American Archaeology, 1530 P Street, N.W., Washington 5, D.C. Remittance should accompany order. The publications of the Society are not available for exchange.

\section{AMERICAN ANTIQUITY}

\section{A Quarterly Review of American Archaeology}

Complete volumes still available are: Vol. $1, \$ 3.00$; Vols. 14-17, 19, 20, $\$ 6.00$; Vol. 26, $\$ 8.00$. Volumes $3-6,11$, and 12 are completely out of print, and all other volumes are out of print in part. Single issues available are: Vol. 1, Nos. 1-4, Vol. 2, Nos. 3, 4, Vol. 7, No. 3, Vol. 8, No. 4, \$1.00 each; Vol. 9, Nos. 3, 4, Vol. 10, No. 3, \$1.25 each; Vol. 13, Nos. 3, 4, Vols. 14-17, Nos. 1-4, Vol. 18, Nos. 3 , 4, Vols. 19, 20, Nos. 1-4, Vol. 21, Nos. 3, 4, Vol. 22, Nos. 2-4, $\$ 1.75$ each; Vols. 23-25, Nos. 2-4, Vol. 26, 1-4, Vol. 27, Nos. 1, 2, \$2.50 each.

\section{MEMOIRS OF THE SOCIETY FOR AMERICAN ARCHAEOLOGY}

Occasional publications of monograph length. Memoirs 1-3, 9, 10, and 12 are out of print.

4. A Reappraisal of Peruvian Archaeology. Assembled by Wendell. C. Bennetr. $x+128$ pages, 72 figures, 6 tables. 1948. $\$ 2.00$.

5. The George C. Davis Site, Cherokee County, Texas. H. Perry Newell and Alex D. Kriegrr. $x v i+255$ pages, 66 figures, 20 tables. 1949. $\$ 3.50$.

6. Archaeology of the Columbia-Frazer Region. Maruan W. Smrrm. viii +46 pages, 4 figures, 3 tables. 1950. Bound and sold with No. 7, $\$ 2.50$.

7. Cattle Point: A Stratified Site in the Southern Northwest Coast Region. Arden R. KrNo. xii + 94 pages, 25 figures, 13 tables. 1950. Bound and sold with No. 6, $\$ 2.50$.

8. Radiocarbon Dating. Assembled by Frederick Johnson. vi +65 pages, 2 figures, 2 tables. 1951. $\$ 1.50$.

11. Seminars in Archaeology: 1955. Edited by RoBerT WAUchope. $x+160$ pages, 6 figures, 5 tables. 1956. $\$ 2.00$.

13. Paracas, Nazca, and Tiahuanacoid Cultural Relationships in South Coastal Peru. Wrunu Duncan Strong. vi +48 pages, 18 figures, 4 tables. 1957. $\$ 1.00$.

14. Danger Cave. Jesse D. Jennings. xii +328 pages, 247 figures, 31 tables. 1957. Available only as University of Utah Anthropological Papers, No. 27, from University of Utah Press, Salt Lake City 12 , Utah. $\$ 6.00$.

15. Modern Yucatecan Maya Pottery Making. Raymond H. Thompson. $x+157$ pages, 48 figures. 1958. $\$ 2.50$.

16. The Belcher Mound: A Stratified Caddoan Site in Caddo Parish, Louisiana. Clarence H. WeBв. xiv +212 pages, 142 figures, 4 tables. 1959. $\$ 3.00$.

17. Prehistoric Agriculture at Point of Pines, Arizona. Richard B. Woonbury. xiv +48 pages, 16 figures, 4 tables. 1961. $\$ 1.50$.

\section{CUMULATIVE INDEX}

A cumulative index of AmErican Antiouity, Vols. 1-25, Memoirs 1-16, and the Notebook is in preparation.

\section{ABSTRACTS OF NEW WORLD ARCHAEOLOGY}

An annual volume of abstracts of the literature of the preceding calendar year, edited by Richard B. Woodbury.

Volume $1-1959$. vi +127 pages; 676 abstracts. 1960 . $\$ 3.50$.

Volume $2-1960$. viii +184 pages; 1124 abstracts. 1961. $\$ 3.50$.

\section{ARCHIVES OF ARCHAEOLOGY}

Occasional publication on Microcard of primary documentation of archaeological investigations and related materials pertaining to the New World. The series is published jointly by the Society for American Archaeology and the University of Wisconsin Press. Order from the University of Wisconsin Press, 430 Sterling Court, Madison 6, Wisconsin. Remittance should accompany order. 